\title{
Letter from Elie Wiesel
}

\author{
Elie Wiesel
}

Published online: 9 June 2010

(C) UNESCO IBE 2010

I have just finished reading this volume; it is good both in terms of its ethics and also its level of research. Congratulations to all the contributors on a remarkable collective work!

The idea of this effort fascinates me: Jewish and non-Jewish researchers from Israel, Germany, and all over the world working together on a theme or collection of themes related to the Shoah. Can there be a more tempting, more useful—and why not say it-a more inspiring project?

From the perspective of history, they all address the same noble concern: identify the evil, unmask it, deprive it of its poisonous power-which is hatred-and then try to understand and to make people understand its incomprehensible nature and extent.

Each of the texts, in its individual way, through its own logic and anguish, appears to me to have as its goal the challenge of ridding society of what separates humans from their destiny.

You should know how deep my belief in education is: Nothing can be more important. Whatever will be the response to the essential questions which confront our society, education must be the principal component in answering them.

Indeed, when an unprecedented tragedy occurs within the annals of history, nothing is easy. How do we communicate such horrors to young children, without risking turning their dreams into nightmares? How do we keep their lives from being filled with melancholy or remorse?

And yet, we must try. It is the only option.

Having said this, certain issues mentioned in this volume cannot and will never be answered. And yet, they are part of our memory.

The key word is: memory. Is this not what unites us, teachers and pupils from everywhere, searching for a sense in that which, in the near and distant past, always will hurt us?

This letter was originally written in French and addressed to Reinhold Boschki.

E. Wiesel $(\bowtie)$

Elie Wiesel Center for Judaic Studies, Boston University, 147 Bay State Road, Boston, MA 02215, USA

e-mail: reinhold.boschki@uni-bonn.de 
You know all too well that I strongly believe that the German post-war generation deserves more than just our sympathy as it shoulders the burden of frightening memories. This generation of German youths certainly deserves our encouragement.

And this encouragement, in its academic context, coming from Jewish youth in Israel and elsewhere, can only create an ambience of fraternal solidarity which can serve as an example to other, distant communities torn apart by a painful past full of torment and fear.

If the new generations use their courage, their curiosity, and their fervour to highlight the ugliness and uselessness of hatred, then the world will resonate with a powerful voice proclaiming a great and true message of hope.

\section{Author Biography}

Elie (Eliezer) Wiesel is a novelist, essayist and professor. A Holocaust survivor, born in Sighet, Romania, he won the Nobel Peace Prize in 1986. In 1958, he published his first book, La nuit, a memoir of his experiences in the concentration camps. He has since authored more than forty books, some of which use these events as their basic material, and he became a tireless spokesman for human rights. He was a visiting scholar at Yale University, and a Distinguished Professor of Judaic Studies at the City College of New York, and since 1976 has been Andrew W. Mellon Professor in the Humanities at Boston University. He has also been awarded the Presidential Medal of Freedom, the United States Congressional Gold Medal, and the Grand Croix of the French Legion of Honor. 